UDC 622.35 .095

I. V. ZENKOV ${ }^{1}$, Professor, Doctor of Engineering Sciences, zenkoviv@mail.ru

A. S. MORIN ${ }^{1}$, Professor, Doctor of Engineering Sciences

V. N. VOKIN 1 , Professor, Candidate of Engineering Sciences

E. V. KIRYUSHINA ${ }^{1}$, Associate Professor, Candidate of Engineering Sciences

${ }^{1}$ Siberian Federal University, Krasnoyarsk, Russia

\title{
CUMULATIVE PRODUCTION POTENTIAL OF QUARRIES TO SUPPLY CRUSHED STONE FACTORIES IN RUSSIA: AN OVERVIEW
}

Introduction

In the territory of Russia, in the period of economic development in the days of the USSR, there were 78 crushed stone plants with the annual production capacity of more than $1 \mathrm{Mt}$ of graded crushed stone. The infrastructure of each plant included a stone quarry and a grinding-andsorting factory for grinding and fractional separation of crushed stone, its storage and shipment to consumers. As a rule, crushed stone was hauled using road and railway transport.

The current financial position of the industry manufacturing construction materials from natural stone depends on implementation of two national projects: Safe and High-Quality Highways and Housing and Urban Environment. In the modern reality of subsoil management in Russia, when crushed stone factories are held by dozens of owners and the accounting control lacks comprehensive data on economic performance and actual production capacities, it is impossible to find out whether total production output agrees or disagrees with the rated capacity. The overall production potential of all crushed stone factories in Russia can be effectively and reliably assessed using the Earth remote sensing techniques. The implementation of this approach in the other branches of the mining industry at the national scale in Russia is described in [1-3].

Various scientific missions are successively being met using satellite imagery information [4-20]. The basic and applied research school of the Siberian Federal University has effectively accomplished a next new project on determination of aggregate potential of all crushed stone factories in Russia using satellite data. The project results are considered to remain relevant for the nearest decade at at least [2].

\section{Research findings}

Aimed to assess the overall production potential of all crushed stone factories in Russia, a certain range of works has been accomplished: locations of operating factories are identified; geographical lots of crushed stone production are delineated; production data and logistics are determined for each quarry; arrangement of mining and haulage machines at the quarries is reviewed; capacities of each quarry in terms of stripping and actual mining are determined; volumes of rock excavation for crushed stone production in each delineated geographical lot are calculated.

In Russia there are a little more than 100 open pit mines which supply crushed stone factories. These quarries provide $90 \%$ output of crushed stone in the industry. Each quarry capacity allows annular production of crushed stone at the level of $1 \mathrm{Mt}$ and more. Moreover, with the increasing scale of production, the product cost essentially reduces. Quarries beyond these standards are withdrawn from the research program.

The crushed stone production operations feature a wide geography, from the central areas in Karelia to the southern regions in the Krasnodar Krai and Primorsky Krai. By the number and concentration of crushed stone factories, this geographical belt is segmented into European Russian, Ural and adjacent area and the largest cluster of Siberia and Russian Far East [2].

European Russia is the most populated part of the country, with high concentration of production. Construction of new housing, motor and rail roads needs a large amount of natural stone material, including graded crushed stone. Considering geology of this sector, the only conclusion is that the demand of this sector for crushed stone of the wanted quality is very difficult to meet. This sector of Russia has always been suffering from deficit of crushed stone despite more than a half of all country's crushed stone factories located here.

The geography of the crushed stone quarrying and production for building and road construction is briefly described below. From satellite data, in the Leningrad Region, along the imagined axis drawn through the towns of Gavrilovo, Vyborg, Kamennogorsk and Kuznechnoe, gabbro and granite fields are developed by 14 quarries with the total annular output of 54.2 Mt (Fig. 1) [2]. There is a developed railway system in the Leningrad Region. This is an important factor of the crushed stone production expansion. Nearly all graded crushed stone is shipped via railroad to the southeast of Russia.

From the remote sensing data, the Republic of Karelia holds 14 temporarily abandoned open pits and 12 operating quarries. The total capacity of the latter amounts to $18.5 \mathrm{Mt}$ of crushed stone annually. The crushed stone production in Karelia has essentially reduced in the recent years as the haulage distance to the consumption points exceeds greatly (by $300-$ $350 \mathrm{~km}$ ) the haulage distance for crushed stone produced in 
the Leningrad Region. In the neighbor Arkhangelsk Region, two operating quarries produce $3 \mathrm{Mt}$ of crushed stone yearly.

In the Vladimir Region, five quarries operate in wide Melekhovo-Fedotovo dolomite field. Large volume of produced crushed stone is consumed by construction and road-making companies in this region and by neighbors. The total capacity of the quarries makes $20 \mathrm{Mt}$ per year. In the Smolensk Region, large Vyazma sand-and-gravel deposit has been developed for more than 50 years. At the moment, the aggregate annual capacity of two quarries makes up to $6 \mathrm{Mt}$ [2].

In the Voronezh Region, Shkurlat granite field is developed. The quarry is assumed the deepest pit in Europe and takes the leading position among the nonmetal quarries. From interpretation of satellite images, this quarry potential enables production of $18 \mathrm{Mt}$ of crushed stone yearly, including annual overburden volume of $4 \mathrm{Mt}$. The quarry supplies nearly all regions in European Russia.

In the Rostov Region and Krasnodar Krai, quarries also produce crushed stone for building construction and roadmaking. By satellite survey, the Rostov Region fields geographically lie inside a triangle with the corners at the towns of Donetsk, Bystrogorsky and Novoshakhtinsk, with a slight drift of one quarry westward of the Donetsk-Novoshakhtinsk line. There are 17 operating quarries in these two regions. The increasing output of crushed stone in the Krasnodar Krai in the recent 15 years is associated with the dynamic development of the national economy thanks to the Sochi Winter Olympic Games, construction of motor and railway bridges to the Crimea Peninsula, building of dwellings and related infrastructure. The total annual production of the local quarries makes 33.8 $\mathrm{Mt}$ of crushed stone [2].

The crushed stone shortage in European Russia is covered by means of railway supplies from the Urals and Orenburg Region. The geography of large dolomite, gabbro, basalt and granite fields is demonstrated in Fig. 2.

In this sector, the industry history and the geology condition the large-scale production of crushed stone. All in all, the Urals and adjacent territories (5 regions) accommodate 22 crushed stone production projects structurally composed of a quarry and a crushing-and-grading plant. Crushed stone is shipped via main lines of Russian Railways. The extensive railway network and the relatively short haulage distances to the consumption points of graded crushed stone in European Russia favor the local production development [2].

In the east of the Orenburg Region, three granite deposits are developed. All crushed stone is shipped to the outside areas via railway. In the Kurgan Region, Sinara basalt deposit has been operated since the 1970s.

The total annular volume of rock mass processed at 22 quarries in the five test regions amounts to $78.4 \mathrm{Mt}$ [2].

Between the Kurgan Region and the western Novosibirsk Region in Russia, there are no crushed stone factories, and these territories experience permanent deficit of crushed stone, which is covered by railway deliveries from the crushed stone-producing regions.

In the Novosibirsk and Kemerovo Regions in Siberia, crushed stone is produced at 9 quarries, including 5 quarries affiliated within a single large mining company. This territory features high concentration of populated communities and the mature motor and rail road network. New motor roads are constructed westward of the Novosibirsk Region, where there is no crushed stone production but the civil and industrial

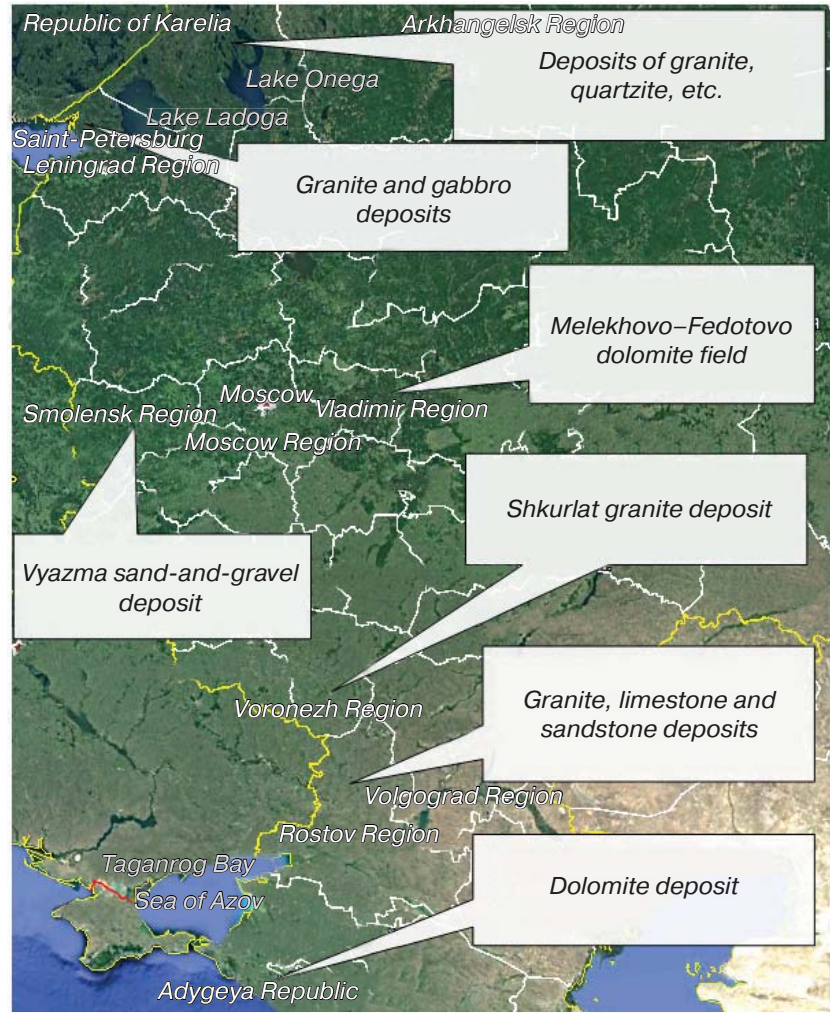

Fig. 1. Layout of mineral reserves for production of crushed stone in European Russia

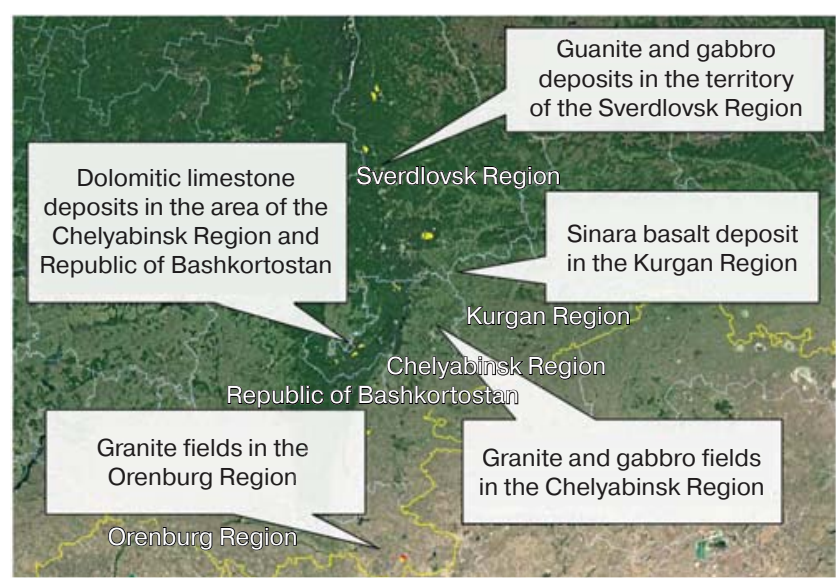

Fig. 2. Layout of nonmetal deposits supplying crushed stone production in the Ural area and adjacent territory

construction infrastructure requires new motor roads to be laid. Thus, big crushed stone quarries clustered in these regions can satisfy the demand in crushed stone for building and road construction from the Novosibirsk Region to the Urals.

Interpretation of the high-resolution images of the Krasnoyarsk Krai territory shows that two large graded crushed stone producers operate in the south. Here, in the Kuragino district, Irba iron ore field was mined-out a few years ago. Post-mining dumps are composed of rocks with low or zero iron content. These rocks are of no commercial interest for the metallurgy but production of crushed stone from these rocks could be relatively inexpensive. This approach is also 
eco-friendly as crushed-stone production causes no damage to natural landscape. In this area, Kuragino keratophyre deposit has been mined for more than 50 years. Crushed stone is mostly used in construction of railroads.

In the Irkutsk Region, a large crushed stone manufacturer operates in the south of the Lake Baikal. Granite and composite gneiss from Angasolka deposit are used in construction of buildings and structures assigned a high rank of criticality.

Remote sensing finds out that mineral mining to supply crushed stone production reduces west eastward in Russia. Concurrently, production capacity of crushed stone factories drops. The situation can be explained by decreasing density of population and industry. The major consumers of crushed stone are Russian Railways and agencies engaged in construction and repair of motor roads.

In the west of Transbaikalia, a large manufacturer produces crushed stone $180 \mathrm{~km}$ southeastward of the Ulan-Ude city. Zhiphegen granite quarry has been operating since the early 19th century when the Trans-Siberian Mainline was launched. Farther eastward to the Amur Region, there is no large production of crushed stone. Inside the Amur Region, crushed stone is manufactured at Talda deposit of porphyry and tuff. Crushed stone is totally shipped to the key consumer - Russian Railways.

In Russian Far East, in the Khabarovsk Region, a single large manufacturer of crushed stone operates $15 \mathrm{~km}$ southward of the Khabarovsk city. Rocks from Korfovsky grandiorite deposit is used to produce concrete of all grades for the civil and industrial engineering, as well as for the motor and rail road construction. In the south of the Priamursky Krai, two large crushed stone production projects operate - at Sibirtsevo deposit of porphyry and dacite and at deposit Pushkarev Klyuch. These quarries are located 112 and $42 \mathrm{~km}$, respectively, northward of the Vladivostok city which currently enjoys rapid development of social, transport and industrial infrastructure.

From satellite survey results, the overall annular volume of processed rock mass at 16 quarries in the eight test regions is estimated as 33.7 Mt [12].

Mineral reserves currently available at operating quarries of granite, dolomite, sand-and-gravel material and other rocks in Russia can supply crushed stone production for the nearest 25-30 years. An exception is the Rostov Region which is faced with the problem of expanding quarries nearby agro-industrial lands, which has been revealed by satellite surveys.

All quarries included in the study were divided into three groups based on their annual capacity. The first group with the production capacity in the range from 1.0 to $2.5 \mathrm{Mt}$ per year embraces 62 quarries. The second group with the annual capacity from 2.6 to $3.9 \mathrm{Mt}$ involves 19 quarries, and the third group of 8 quarries produces 4 to $6 \mathrm{Mt}$ of crushed stone yearly. The grouping sets asides two quarries having super high capacities of 7.5 and $18 \mathrm{Mt}$ in Pervouralsk and Shkurlat fields. These production capacities were included in the total production potential of the sector all the same.

According to the remote sensing data, the operating quarries feature actual cutting on 3-4 benches, or less frequently on 5-7 benches, and only Pervouralsk, Shkurlat and Kuragino quarries have 10-12 production benches. The heights of the highwall in these quarries are 120,170 and $110 \mathrm{~m}$, respectively.

The total production of crushed stone in European Russia amounts to $135.3 \mathrm{Mt}$, and the volume of stripping makes 35.4 Mt annually. The average stripping ratio is $0.2616 \mathrm{t} / \mathrm{t}$. The overall annual output of crushed stone at the factories in the Ural Region and in adjacent areas (Republic of Bashkortostan, Orenburg and Kurgan) makes 66.5 Mt. By the authors' estimate, the annual volume of stripping is not less than $12.0 \mathrm{Mt}$. The averaged stripping ratio is $0.1807 \mathrm{t} / \mathrm{t}$. The total annual production output of crushed stone in the regions of Siberia and Russian Far East is $29.5 \mathrm{Mt}$ at the annual stripping volume of 4.2 Mt. The averaged stripping ratio in this sector is $0.1424 \mathrm{t} / \mathrm{t}$ [2].

At the final stage of the studies using satellite survey, the authors have obtained the modern-day structure of crushed stone quarrying in the Russian Federation. The result allows evaluating the cumulative production potential of the crushed stone industry.

All in all in Russia, 91 quarries produce mineral raw material for crushed stone factories. The annual capacity of crushed stone factories ranges from 1.2 to $18 \mathrm{Mt}$. In eight regions in European Russia, 53 crushed stone factories operate. In the territory of the Middle and Southern Urals, 22 crushed stone operate. In eight regions of Siberia and Russian Far East, 16 quarries supply crushed stone production.

The mining and haulage equipment used in crushed stone quarrying in Russia is listed below [2].

Size of mining and haulage equipment involved in production of mineral raw material for crushed stone factories in Russia, machines

Drilling machines (to $250 \mathrm{~mm}$ drilling)

Draglines ESH-5/45; 4/40

Crawler-mounted excavators EKG-5A

Crawler-mounted excavators EKG -8i; EKG-10 209

Hydraulic excavators with bucket capacity to $10 \mathrm{~m}^{3}$

Dump trucks with capacity from 20 to $55 t$

Electric-industrial locomotives OPE-1

159

Open-pit locomotives EL-21

Railway dump cars 2VS-105

Below, we review briefly the mining and haulage equipment structure in 22 mining regions of Russia. The scope of quarrying encompasses all processes required for crushed stone production, from blasting to dumping. Drilling machines are distributed in quarries in accordance with the production capacity. The strength of rocks pre-determines their preliminary weakening by blasting. Drilling machines are only not used in Vyazma sand-and-gravel field.

All draglines are employed in stripping at Vyazma and Shkurlat quarries.

Excavators have either rope or hydraulic drives. Open pit mines usually combine the rope-driven excavators with bucket capacity of 5-10 $\mathrm{m}^{3}$ with the hydraulically driven machines with bucket capacity of 2-10 $\mathrm{m}^{3}$. Excavators EKG-5A are chiefly (79\%) used in excavation and only a small number of the machines (21\%) are employed in take-in of overburden at external dumps piled with the help of railway vehicles and in loading of crushed stone from warehouses to railway dump cars. All excavators EKG-8i and EKG-10 operate in the Voronezh Region, at Shkurlat granite quarry. The ratio of dump truck capacity to excavator bucket capacity conforms with the proportion (4-8)/1. This means that complete loading of a dump truck requires that an excavator performs 4-8 operating cycles (depending on the model of the excavator and on the capacity of a dump truck).

Almost all crushed stone quarries use road transport. Specific weights of dump trucks with capacities of 20,30, 40 and $55 \mathrm{t}$ in Russia are 61, 18, 15 and $6 \%$, respectively. Railway 
transport is operated at two granite and gabbro quarries with mining fronts longer than $2 \mathrm{~km}$ along the top bench, which ensures essential volume of carriage at a level of $7 \mathrm{Mt}$ and more per year. The geological conditions at Shkurlat and Pervouralsk deposits enable large-scale use of railway transport in removal of rocks from the quarries. Dump trucks are operated in haulage of 3 to $5 \%$ rock mass volume to ground surface [2].

By our estimates, the volume of rock mass processed during manufacturing of all kinds of crushed stones in Russia makes 282.8 Mt annually. The volume of produced crushed stone is $231.2 \mathrm{Mt}$ per year, and the volume of stripping is 51.6 Mt per year. The fleet of mining and haulage equipment operated at crushed stone quarries in Russia totals 1522 machines. These include 134 drilling machines, 5 draglines, 368 crawlermounted excavators, 807 dump trucks with the capacity of 20-55 $t$ and 198 units of railway transport.

\section{Conclusions}

The remote sensing data analysis has allowed identification of Russian regions with quarries that supply mineral raw material for production of crushed stone for building and road construction. The review of the quarrying systems and mining and haulage equipment has made it possible to determine production capacities of crushed stone factories. The cumulative annual production potential of all crushed stone factories operating in Russia is determined using the data on mining and haulage machines from the high-resolution satellite images.

According to the authors' estimate, the total annual production volume of all kinds of crushed stone is 231-232 Mt. For the specified territorial sectors in Russia - European Russia, Ural and adjacent areas, Siberia and the Far East - percentage in the structure of the total crushed stone production makes 58.5, 28.7 and $12.8 \%$, respectively. These figures should be used in validation of a range of works in implementation of the current and future national projects: Safe and HighQuality Highways and Housing and Urban Environment.

\section{References}

1. Zenkov I. V., Zhukova V. V., Nefedov B. N. et al. Open pit mines of nonferrous metallurgy in Russia from space. Mining and disturbed land ecology. Krasnoyarsk : SFU, 2019. 604 p.

2. Zenkov I. V., Lukianova A. A., Anishchenko Yu. A. et al. Crushed stone quarries in Russia from space. Mining and disturbed land ecology. Krasnoyarsk: SFU, 2020. 328 p.

3. Zenkov I. V., Lukianova A. A., Yuronen Yu. P. et al. Open pit mines at nonmetallic deposits. Mining and disturbed land ecology. Krasnoyarsk: SFU, 2020. 652 p.

4. Bolin J. A., Schoeman D. S., Pizà-Roca C., Scales K. L. A current affair: entanglement of humpback whales in coastal shark-control nets. Remote Sensing in Ecology and Conservation. 2020. Vol. 6, Iss. 2. pp. 119-128.

5. Taylor A., Biswas T., Randall J. M., Klausmeyer K., Cohen B. Parched pines: a quantitative comparison of two multi-year droughts and associated mass mortalities of bishop pine (Pinus muricata) on Santa Cruz Island, California. Remote Sensing in Ecology and Conservation. 2020. Vol. 6, Iss. 1. pp. 20-34.

6. Ancin-Murguzur F. J., Munoz L., Monz C., Hausner V. H. Drones as a tool to monitor human impacts and vegetation changes in parks and protected areas. Remote Sensing in Ecology and Conservation. 2020. Vol. 6, Iss. 1. pp. 105-113.

7. Wagner F. H., Sanchez A., Tarabalka Y., Lotte R. G., Ferreira $M$. P. et al. Using the $U$-net convolutional network to map forest types and disturbance in the Atlantic rainforest with very high resolution images. Remote Sensing in Ecology and Conservation. 2019. Vol. 5, Iss. 4. pp. 360-375.

8. Kamm M., Reed J. M. Use of visible spectrum UAS photography for land cover classification at nest sites of a declining bird species (Falco sparverius). Remote Sensing in Ecology and Conservation. 2019. Vol. 5, Iss. 3. pp. 259-271.

9. Mirkovic D., Stepanian P. M., Wainwright Ch. E., Reynolds D. R., Myles H. M. Menz. Characterizing animal anatomy and internal composition for electromagnetic modelling in radar entomology. Remote Sensing in Ecology and Conservation. 2019. Vol. 5, Iss. 2. pp. 169-179.

10. Beresford A. E., Sanderson F. J., Donald P. F., Burfield I. J., Butler A. et al. Phenology and climate change in Africa and the decline of Afro-Palearctic migratory bird populations. Remote Sensing in Ecology and Conservation. 2019. Vol. 5, Iss. 1. pp. 55-69.

11. Muir J., Phinn S., Eyre T., Scarth P. Measuring plot scale woodland structure using terrestrial laser scanning. Remote Sensing in Ecology and Conservation. 2018. Vol. 4, Iss. 4. pp. 320-338.

12. Fernandes K., van der Heyde M., Bunce M., Dixon K., Harris R. J. DNA metabarcoding - new approach to fauna monitoring in mine site restoration. Restoration Ecology. 2018. Vol. 26, Iss. 6. pp. 1098-1107.

13. Hofmeester T. R., Young Sh., Juthberg S., Singh N. J., Widemo F. et al. Using by-catch data from wildlife surveys to quantify climatic parameters and timing of phenology for plants and animals using camera traps. Remote Sensing in Ecology and Conservation. 2020. Vol. 6, Iss. 2. pp. 129-140.

14. Neumann C., Behling R., Schindhelm A., Itzerott S., Weiss G. et al. The colors of heath flowering - quantifying spatial patterns of phenology in Calluna life-cycle phases using highresolution drone imagery. Remote Sensing in Ecology and Conservation. 2020. Vol. 6, Iss. 1. pp. 35-51.

15. Erlandsson R., Stoessel M., Skanes H., Wennbom M., Angerbjorn A. An innovative use of orthophotos - possibilities to assess plant productivity from colour infrared aerial orthophotos. Remote Sensing in Ecology and Conservation. 2019. Vol. 5, Iss. 4. pp. 291-301.

16. Hislop S., Jones S., Soto-Berelov M., Skidmore A., Haywood A. et al. High fire disturbance in forests leads to longer recovery, but varies by forest type. Remote Sensing in Ecology and Conservation. 2019. Vol. 5, Iss. 4. pp. 376-388.

17. Niedballa J., Wilting A., Sollmann R., Hofer H., Courtiol A. Assessing analytical methods for detecting spatiotemporal interactions between species from camera trapping data. Remote Sensing in Ecology and Conservation. 2019. Vol. 5 , Iss. 3. pp. 272-285.

18. Pina-Covarrubias E., Hill A. P., Prince P., Snaddon J. L., Rogers A. et al. Optimization of sensor deployment for acoustic detection and localization in terrestrial environments. Remote Sensing in Ecology and Conservation. 2019. Vol. 5, Iss. 2. pp. 180-192.

19. Attanayake A. U., Xu D., Guo X., Lamb E. G. Long-term sand dune spatio-temporal dynamics and endemic plant habitat extent in the Athabasca sand dunes of northern Saskatchewan. Remote Sensing in Ecology and Conservation. 2019. Vol. 5, Iss. 1. pp. 70-86.

20. Torrent L., López-Baucells A., Rocha R., Bobrowiec P. E. D., Meyer C. F. J. The importance of lakes for bat conservation in Amazonian rainforests: an assessment using autonomous recorders. Remote Sensing in Ecology and Conservation. 2018. Vol. 4, Iss. 4. pp. 339-351. 国 